\title{
How does the market value corporate sustainability performance?
}

\author{
Isabel Costa Lourenço ${ }^{1}$ \\ UNIDE, Lisbon University Institute (ISCTE-IUL), Portugal \\ Manuel Castelo Branco \\ Faculty of Economics, University of Porto, Portugal \\ José Dias Curto \\ UNIDE, Lisbon University Institute (ISCTE-IUL), Portugal \\ Teresa Eugénio \\ School of Technology and Management, Polytechnical Institute of Leiria, portugal
}

\begin{abstract}
This study provides empirical evidence on how corporate sustainability performance (CSP), as proxied by membership of the Dow Jones Sustainability Index, is reflected in the market value of equity. Using a theoretical framework combining stakeholder theory and resource-based perspectives, we develop a set of hypotheses that relate the market value of equity to CSP. For a sample of North American firms, our preliminary results show that CSP has significant explanatory power for stock prices over the traditional summary accounting measures such as earnings and book value of equity. However, further analyses suggest that we should not focus on corporate sustainability itself. Our findings suggest that what investors really do is to undervalue large profitable firms with low level of CSP. Firms with incentives to develop a high level of CSP not engaging on such strategy are, thus, penalized by the market.
\end{abstract}

KEYWORDS: corporate sustainability, value relevance

\footnotetext{
${ }^{1}$ Corresponding author: Isabel Lourenço, Avenida Forças Armadas, 1649-026 Lisboa, Portugal, isabel.lourenco@ iscte.pt.
} 


\section{INTRODUCTION}

In the last decade, society has begun to demand that firms carry out policies that move toward sustainable development. Sustainable philosophy assumes that we abandon a narrow version of classical economic theory and develop corporate strategies that include goals that go beyond just maximizing shareholders' interests. Attention is directed to the demands of a wider group of stakeholders, since the firm's success depends on stakeholder's satisfaction (Lopez et al., 2007).

Sustainable development represents an ethical concept related to fight against poverty and protect the environment simultaneously and on a macro-level (Baumgartner and Ebner, 2010). When incorporated by the firm, it is called corporate sustainability (CS) and it contains, like the former concept, three aspects: economic, environmental and social (ibid.). Corporate sustainability performance (CSP) measures the extent to which a firm embraces economic, environmental, social and governance factors into its operations, and ultimately the impact they exert on the firm and society (Artiach et al., 2010).

Engagement in activities promoting sustainable development is increasingly analysed as a source of competitive advantage. For example, some authors argue that "firms should pursue green management practices only when it is in their self-interest to do so" (Siegel, 2009, p.14) or that decisions regarding engagement in such activities "should be considered as a form of strategic investment" (McWilliams et al., 2006, p. 4). For managers to consider engaging in CS they need to have some kind of expectations that it will bring improved performance. Cochran and Wood (1984, p. 42) noted long ago that if it were possible to show that a positive relationship existed between engagement in socially and environmentally responsible activities and social performance, "management might be encouraged to pursue such activities with increased vigour or to investigate the underlying causes of the relationship."

An important stream of research tries to establish a business case for sustainable activities by empirically testing the relationship between corporate sustainability and firm performance. Researchers try to analyse whether firms which are perceived as sustainable out-perform or under-perform firms which are not perceived in the same way. Some mixed results can be found. There is evidence both of a negative relation (López et al., 2007), no relation (Curran and Moran, 2007; García-Castro et al., 2010; Surroca et al., 2010) and a positive relation (Lo and Sheu, 2007; van Dijken, 2007; Consolandi et al., 2009; Cheung, 2010; Wagner, 2010) between CSP and corporate financial performance (CFP). 
This study contributes to the extant literature on this issue by investigating the way as the market views CSP, as proxied by membership of the Dow Jones Sustainability Index. Using a multi-theoretical framework which combines stakeholder and resource-based perspectives (RBP) (Hillman and Keim, 2001; Surroca, 2010; Wahba, 2008), a set of hypotheses are developed that relate the market value of equity with CSP, considering the interaction of size and profitability with CSP. In this study, companies are considered to engage in CS activities to conform to stakeholder norms and expectations about how their operations should be conducted, because they expect that having good relations with their stakeholders is susceptible of leading to increased financial returns by assisting in developing valuable intangible assets (resources and capabilities) which can be sources of competitive advantage because such assets can differentiate a company from its competitors.

The empirical analysis relies on the largest 600 firms from Canada and the United States of America in the Dow Jones Global Total Stock Market Index (DJGTSM), which includes two sets of firms, those that belong to the DJSI North America (higher level of CSP) and those that belong to the DJGTSM but are not included in the DJSI North America (lower level of CSP).

Our preliminary results indicate that CSP has significant explanatory power for stock prices over the traditional summary accounting measures such as earnings and book value of equity. However, further analyses suggest that we should not focus on the corporate sustainability itself. Our findings show that what investors really do is to undervalue large profitable firms with low level of CSP, which face greater public scrutiny and pressures from stakeholders.

This study contributes to the literature in several ways. First, we bring additional evidence on the value relevance of non-financial information. Some previews studies has already find a significant relation between the market value of equity and non-financial information, like network advantages (Rajgopal et al., 2003), environment performance (Hassel et al., 2005), eco-efficiency (Sinkin et al., 2008) or technological conditions (Matolcsy and Wyat, 2008). We extend these conclusions to the issue of CSP. Second, we provide additional evidence on the relationship between CSP and firms' financial performance. Recent research provides mixed evidence on this issue (e.g. Consolandi et al., 2009; Wagner, 2010; López et al., 2007; Surroca et al., 2010). This paper reports evidence of a positive relation between CSP and firm performance. Finally, we contribute with new empirical evidence supporting that firms with incentives to develop a high level of CSP not engaging on such strategy are penalized by the market. Artiach et al. (2010) have already demonstrated that size and profitability are incentives to invest in sustainability. We also find that size and profitability are issues that 
matter in terms of CSP. In addition, our results suggest that the information on the relation between size, profitability and level of CSP is relevant for investors.

The remainder of the paper is organized as follows. Section 2 analyses the concept of corporate sustainability and review the literature on the relationship between CSP and financial performance. Section 3 develops the theoretical framework of this study. Section 4 describes the research design and section 5 analyzes the empirical results. Finally, section 6 presents the summary and concluding remarks.

\section{BACKGROUND}

\subsection{CORPORATE SUSTAINABILITY}

Engaging in activities to contribute to sustainable development has emerged as an important dimension of corporate voluntary practice. The concept of sustainable development simultaneously integrates the consideration of economic growth, environmental protection, and social equity. Dyllick and Hockerts (2002, p. 131) define corporate sustainability as "meeting the needs of a company's direct and indirect stakeholders (employees, clients, pressure groups, communities, etc.), without compromising its ability to meet the needs of future stakeholders as well." The notion of CS is nowadays related to issues such as environmental protection, health and safety at work, relations with local communities and relations with consumers.

Although other concepts have been proposed over the years to conceptualize business and society relations, such as corporate social responsibility (CSR), CS has become the concept used most widely to address these relationships. Even though some authors propose distinctions between CSR and corporate sustainability (Cheung, 2010; Lo and Sheu, 2007; López et al., 2007; van Marrewijk, 2003), widely acknowledged definitions of CSR relate it with sustainable development. Holme and Watts (2000, p. 10) have defined CSR as the firm's commitment to contribute to sustainable economic development, working with employees, their families, local communities and society at large to improve the general quality of life. According to the European Commission (2002, p. 7), these two concepts may be considered as being "intrinsically linked" and CSR can be seen as the business contribution to sustainable development. Firms are seen as contributing to sustainable development "by managing their operations in such a way as to enhance economic growth and increase competitiveness whilst ensuring environmental protection and promoting social responsibility, including consumer interests" (ibid.). Thus, in this paper these concepts are considered to address the same basic issues, in the sense that they all are about companies' impacts on, relationships with, and responsibilities to, society. 
Some authors see the contribution of these concepts as just the reminder that the search for profit should be constrained by certain social considerations (Valor, 2005). However, social and environmental performances are increasingly seen as a source of competitive advantage and not as an end in themselves. Perspectives on the involvement of companies in socially and environmentally responsible activities evolved from being regarded as detrimental to a firm's performance, to being considered as somehow benefiting the firm as a whole (see, for example, see, for example, Porter and Kramer, 2002, 2006; Falck and Heblich, 2007; Sasse and Trehan, 2007; Heslin and Ochoa, 2008).

Engagement in activities leading to sustainable development is increasingly considered as somehow benefiting the company as a whole (see, for example, Porter and Kramer, 2002, 2006). Some authors argue that decisions regarding engagement in such activities should be treated by managers "precisely as they treat all investment decisions" (McWilliams and Siegel, 2001, p. 125) or that "it should be considered as a form of strategic investment” (McWilliams et al., 2006, p. 4).

Engaging in activities leading to sustainable development involves costs as it might require, for example, purchasing environmentally friendly equipment, implementing stricter quality controls, or new health, safety and environmental programs. Sustainability reporting also involves costs such as those related to data collection, communication and audit. The investments required may not have an immediate pay-off. In fact, whereas the costs involved are usually short term in nature or continuous outflows, the benefits are often long term.

For example, certifying an environmental management system for ISO 14001 "is neither easy nor cheap" (Bansal and Bogner, 2002, p. 274). Furthermore, whereas the costs of such endeavour "are very real", the benefits which accrue to the firm, either economic or institutional, "are often long term, diffused, and sometimes invisible", and they are derived "not only from improved performance but also from avoiding damaging impacts." (op. cit., p. 278)

Disregarding aspects such as personal values, for managers to consider engaging in CS they need to have some kind of expectations that it will bring improved performance. The question that arises is what kind of benefits CS has that can lead to improved performance. Benefits which accrue to firms from CS include those associated to some kind of competitive advantage. It may increase sales and profits by promoting a firm's products and services. Because consumers often prefer firms that are or are seen to be socially responsible, it is likely that social responsibility and disclosure can also be helpful in preserving old clientele or build up a new one. It is also true that some firms select their suppliers according to their social performance. 
The many cases in which engagement in activities leading to sustainable development are explained by straightforward efforts to enhance sales or the loyalty and satisfaction of employees may reasonably be assimilated to the normal profit seeking functions of management. However, there are many other cases in which such direct association is impossible of being established, but in which it is undoubtedly the creation of a publicly favourable corporate reputation that appears as a likely reason. In fact, in spite of a firm which engages in these activities and appear to receive nothing in return could be said to be engaging in a purely "philanthropic" activity, it remains that in most cases some intangible benefit is obtained, such as public approval of its image as a responsible citizen. As McWilliams et al. (2006, p. 4) put it "even when it is not directly tied to a product feature or production process", the engagement in such activities "can be viewed as a form of reputation building or maintenance".

\subsection{CORPORATE SUSTAINABILITY AND CORPORATE PERFORMANCE}

The arguments that for some time have been presented for CS arise, at least in part, from the classical idea that the objective of business is to maximise shareholder wealth and that a firm should engage in socially responsible activities only if it allows value to be created. Siegel $(2009$, p.14) contends that "firms should pursue green management practices only when it is in their self-interest to do so".

In this perspective, decisions regarding CS are considered as a form of strategic investment (McWilliams et al., 2006). Rather than being seen as a cost, CS is perceived as a valuable resource which can be used to improve the future performance of the firm. The business case for CS can be defined as "a strategic and profit-driven corporate response to environmental and social issues caused through the organization's primary and secondary activities" (Salzmann et al., 2005, p. 27).

An important stream of research on CS tries to establish a business case for socially responsible activities by empirically testing the relationship between CS and firm performance. This relationship has been an important topic of debate at least since the 1970s. Early work on the link between CS and firm performance was made by Moskowitz (1972) and Vance (1975). Moskowitz (1972) looked at the relationship between social responsibility and share prices based on 14 cases, arguably offering limited external validity. Vance (1975) took the 14 firms studied by Moskowitz in 1972, finding that they had underperformed the Dow Jones and Standard and Poor indices and concluding that socially responsible firms were a poor risk for investors. However, as Aupperle et al. (1985) pointed out the subjectively selected small sample makes these conclusions potentially unreliable. 
Given the vastness of the literature about the relationship between CS and firm performance and the quality of extant reviews, a comprehensive review of this research is not offered in the discussion which follows. Rather, we will focus on the extant reviews and on empirical and theoretical studies deemed relevant to the present study.

It is difficult to say if firms which are perceived as sustainable out-perform or under-perform firms which are not perceived in the same way. The most recent meta-analyses analysing the relationship between corporate sustainable performance (CSP) and corporate financial performance confirms the idea that they are positively linked (Roman et al., 1999; Orlitzky et al., 2003; Margolis and Walsh, 2003; Wu, 2006; van Beurden and Gössling, 2008). However, although there may be some evidence of a positive association, assessments are complicated in view of the imperfect nature of the studies (criticisms of omission of controls, lack of causality and other methodological problems) as well as of the range of qualitative factors which contribute to financial performance, including employee morale, corporate image, reputation, public relations, goodwill and popular opinion (Lantos, 2001)

Surveys of the numerous studies about the relationship between CSR and firm performance that have been undertaken until the early 1980s and discussions of the problems with the measurement of CSR were offered namely by Ullmann (1985) and Aupperle et al. (1985). Ullmann (1985, p. 549) refers to the findings obtained by these studies as indicating "no clear tendency", whereas Aupperle et al. (1985, p. 460) describe those findings as "varying results".

Ten years later, Pava and Krausz (1996) and Wood and Jones (1995) offered updated reviews of the empirical evidence on the relationship between CSR and firm performance. Wood and Jones (1995, p. 261) qualified such relationship as "still ambiguous" and offered several reasons for that: lack of theory; problems with measures of social performance; lack of methodological rigor in many studies; and "confusion about which stakeholders are represented by which measures". Nonetheless, they highlighted the clear evidence that bad social performance is detrimental to a firm's financial performance.

Pava and Krausz (1996, p. 322) revealed an important and unappreciated empirical regularity: "Nearly all empirical studies to date have concluded that firms which are perceived as having met social responsibility criteria have either outperformed or performed as well as other firms that are not necessarily socially responsible." Their own study's findings suggested that social responsible firms did not performed worse than the other firms and that some evidence suggested a positive relationship between social responsibility and firm performance. 
Griffin and Mahon (1999), Margolis and Walsh (2003), Orlitsky et al. (2003), and Roman et al. (1999) provide more recent surveys of the empirical research on the relation between CS and firm performance. Results from this research generally indicate a positive but weak correlation between the two. These reviews also suggest that the empirical results, while positive overall, may prove to be illusory given the imperfect nature of the studies (problems related to the measurement both of CS and financial performance, criticisms of omission of controls, lack of causality and other methodological problems).

In a more recent survey of the empirical research, van Beurden and Gössling (2008) consider that there is clear empirical evidence for a positive correlation between corporate social and financial performance. They argue that authors who contend the opposite refer to outdated material. The majority of the studies analysed by these authors found a positive relationship between corporate social performance (CSP) and corporate financial performance (CFP) (68\%), whereas 26\% show no significant relationship between CSP and CFP. Only two studies (6\%) show a negative relationship between CSP and CFP.

However, more recent research still provides mixed results. There is evidence both of a negative relation (López et al., 2007), no relation (Curran and Moran, 2007; García-Castro et al., 2010; Surroca et al., 2010) and a positive relation (Lo and Sheu, 2007; van Dijken, 2007; Consolandi et al., 2009; Cheung, 2010; Wagner, 2010) between CSP and CFP.

López et al. (2007) analysed whether there are significant differences in performance between firms which adopted sustainability practices, ratified by their belonging to the DJSI, and firms not included in the DJSI because they have not fulfilled its requirements. They analysed the link between the accounting-based performance indicators and CS, and found that short-term negative impact on performance is produced.

Curran and Moran (2007) used the announcements of the constituents of the FTSE4Good UK 50 Index as the proxy for CSR. They test whether inclusion in, or deletion from, the FTSE4Good Index results in a positive (negative) impact on share price. Their results show a trend that positive announcements lead to positive movements in share price (daily returns) and negative announcements lead to negative movements in share price. However, these results are not statistically significant.

García-Castro et al. (2010) used the most complete KLD panel data available at the time (1991-2005). Their results suggest that KLD does not impact performance. They argue that the positive relationship found in most of the previous research on the link between SP and FP becomes a non-significant or even a negative relationship when endogeneity is properly taken into account. 
Surroca et al. (2010) used an international database provided by Sustainalytics Responsible Investment and analysed 599 companies from 28 countries. Their results indicate that there is no direct relationship between CS and financial performance, rather an indirect relationship that relies on the mediating effect of a firm's intangible resources.

Lo and Sheu (2007) examine whether corporate sustainability has an impact on market value using large US non-financial firms from 1999 to 2002 . They used listing in the DJSGI USA as the proxy for corporate sustainability and the Tobin's $\mathrm{q}$ as the proxy for firm value. Their key finding is that sustainable firms are rewarded with higher valuations in the market place.

van Dijken (2007) analysed performance of 90 shares of the US Dow Jones Sustainability Index by comparing their return with the relevant indexes, with the respective industry and on a risk-adjusted basis, for the six years and the ten years ended 30 June 2006. She found that stocks from companies with high CSP outperformed the market and their peers over extensive periods of time, with reasonably low risk.

Consolandi et al. (2009) examine whether inclusion in, or deletion from, the Dow Jones Sustainability Stoxx Index (DJSSI), an index for European corporations, results in a stock market reaction. Their results, which namely show positive (negative) excess returns for companies included in (deleted from) the DJSSI over the period considered, suggest that the evaluation of the CSR performance of a firm is a significant criterion for asset allocation activities.

Cheung (2010) analyzes the impacts (measured in terms of stock returns, risks and liquidity) of index inclusions and exclusions on corporate sustainable firms by studying a sample of US stocks that are added to or deleted from the Dow Jones Sustainability World Index over the period 2002-2008. Findings suggest that US investors do value $\mathrm{CS}$, but in a temporary way.

Wagner (2010) analyses the link between CSP and economic performance. He uses the KLD ratings as a CSP proxy and the Tobin's q was chosen as the variable measuring economic performance. Findings suggest a positive association of CSP with economic performance, as measured by Tobin's q, and that advertising intensity moderates the association of CSP and economic performance.

Our study contributes to the extant body of literature by providing additional evidence on a positive relationship between CSP and financial performance. Further, we bring new evidence supporting that firms with incentives to develop a high level of CSP not engaging on such strategy are penalized by the market. 


\section{THEORY AND HYPOTHESES DEVELOPMENT}

The theoretical framework adopted in this study combines stakeholder theory and resource-based perspectives (RBP). Some authors already provided important studies in which similar combinations were attempted (see, for example, Bansal, 2005; Hillman and Keim, 2001; Ruf et al., 2001; Surroca et al., 2010; Wahba, 2008).

Post et al. (2002, p. 8) define the stakeholders of a company as the "individuals and constituencies that contribute, either voluntarily or involuntarily, to its wealth-creating capacity and activities, and who are therefore its potential beneficiaries and/or risk bearers." A company's stakeholders are seen as those who supply critical resources, place something of value "at risk," and have sufficient power to affect its performance. The principal means of sustaining and enhancing a company's wealth-creating capacity are the linkages between the company and its stakeholders (ibid.). Stakeholders have three roles: they are the sources of expectations about what constitutes desirable and undesirable company performance, defining the norms for corporate behaviour; they experience the effects of corporate behaviour; and they evaluate the outcomes of companies' behaviours in terms of how they have met expectations and have affected the groups and organizations in their environment (Wood and Jones, 1995, p. 231). From a stakeholder theory perspective, CSP can be assessed in terms of a company meeting the demands of its multiple stakeholder groups, and companies must seek to satisfy their demands "as an unavoidable cost of doing business" (Ruf et al., 2001, p. 143).

Stakeholder theory can be complemented by the RBP since firms may view meeting stakeholder demands as a strategic investment, requiring commitments beyond the minimum necessary to satisfy stakeholders (Ruf et al., 2001). Engaging in CS activities when these are expected to benefit the company is a behaviour that can be examined through the lens of the RBP (Branco and Rodrigues, 2006; Gallego-Álvarez et al., 2010; Hussainey, and Salama, 2010; McWilliams et al., 2006; Siegel, 2009; Surroca et al., 2010). The RBP suggest that companies generate sustainable competitive advantages by effectively controlling and manipulating their resources that are valuable, rare, cannot be perfectly imitated, and for which no perfect substitute is available (see, for example, Barney, 1999; Bowman and Ambrosini, 2003; Kraaijenbrink et al., 2010; Pertusa-Ortega et al., 2010).

Companies engage in CS because it is acknowledged that some kind of competitive advantage accrues to them. CS is seen as providing internal or external benefits, or both (Branco and Rodrigues, 2006; Orlitzky et al., 2003). Investments in socially and environmentally responsible activities have internal benefits by helping a company in developing new resources and capabilities which are related to know-how and corporate culture. 
These resources and capabilities, which are acquired internally, would then lead to more efficient use of resources. Investing in social responsibility activities has important consequences on the creation or depletion of fundamental intangible resources, namely those associated with employees.

Effective human resource management can cut costs and enhance employees' productivity. CS can be demonstrated to have positive effects on employees' motivation and morale, as well as on their commitment and loyalty to the company (Peterson, 2004; Brammer et al., 2007; Carmeli et al., 2007). Sustainable employment practices such as fair wages, a clean and safe working environment, training opportunities, health and education benefits for workers and their families, provision of childcare facilities, flexible work hours and job sharing, can bring direct benefits to a company by increased morale and productivity, while reducing absenteeism and staff turnover. As well as productivity benefits, companies also save on costs for recruitment and training of new employees (Vitaliano, 2010).

The external benefits of CS are related to its effect on corporate reputation (Branco and Rodrigues, 2006; Gallego-Álvarez et al., 2010; Hussainey, and Salama, 2010; Orlytzky et al., 2003; Orlytzky, 2008). Corporate reputation has been identified as one of the most important intangible resources that provide a firm sustainable competitive advantage (Roberts and Dowling, 2002). In effect, several studies found a positive relationship between a firm's reputation and its financial performance (Fombrun and Shanley, 1990; Roberts and Dowling, 2002). Companies with a good CS reputation are able to improve relations with external actors such as customers, investors, bankers, suppliers and competitors. They also attract better employees or increase current employees' motivation and morale as well as their commitment and loyalty to the company, which in turn may improve financial outcomes. Stakeholders ultimately control a firm's access to scarce resources and firms must manage their relationship with key stakeholders to ensure that such access to resources is maintained (Roberts, 1992).

According to Fombrun et al. (2000), firms can obtain benefits from engagement in socially and environmentally responsible activities because, on the one hand, it helps firms and their employees to build community ties and become socially integrated, and, on the other hand, it assists firms in building reputational capital that improve their ability to negotiate more attractive contracts with suppliers and governments, to charge premium prices for goods and services offered, and to reduce its cost of capital. It not only generates reputational gains that improve a firm's ability to attract resources, enhance its performance, and build competitive advantage, but also mitigates the risk of reputational losses that can result from alienating key stakeholders. 
An important recent study by Hussainey and Salama (2010) investigates whether corporate environmental reputation (CER) make investors more confident/less uncertain when they anticipate firms' future earnings change by analysing the association between CER and share price anticipation of earnings. They use the future earnings response coefficient (FERC) as a proxy for the stock market's ability to anticipate the firms' future earnings, and predict higher FERCs for firms with higher levels of CER scores. They find that higher levels of CER are associated with stock prices that are more informative about future earnings. They argue that the results obtained show that environmental reputation increases the stock market's ability to anticipate future earnings change, suggesting that CER provides value-relevant information for investors to anticipate future earnings.

In sum, CS can raise benefits in the long run namely through improved relations with stakeholders and reduced cost of conflicts with them, reputation creation, employee productivity. All these aspects make firms more attractive to investors. Higher levels of CSP are subject to lower economic uncertainty, more predictable earnings, and lower risk for investors. Thus, we expect that:

H1: The market undervalues firms with a lower level of CSP, when compared with firms with a higher level of CSP.

As companies grow larger their visibility increases and they become more susceptible to the scrutiny of their stakeholders and hence more vulnerable to the potential adverse reactions of these groups. Large companies, on average, are more diversified across geographical and product markets which means that they have larger and more diverse stakeholder groups (Brammer and Pavelin, 2004).

Artiach et al. (2010) demonstrate that larger firms are more likely to have a higher level of CSP. Larger firms are more visible politically and so draw greater attention from the general public, government and other stakeholders. They are more likely to create corresponding larger social problems because of the sheer scale and prominence of their activities. Thus, a passive or even negative response to stakeholder's demands is unlikely to be a successful strategy for big firms which face greater public scrutiny and external pressures.

Godfrey et al. (2009, p. 430) suggest that firms with a larger market presence incur more risk than their smaller counterparts. They argue that a larger market presence translates into more transactions, which lead to a higher probability of negative events ("there are simply more opportunities for negative outcomes") (ibid.). The consequence is that larger firms should be more willing to engage in socially and environmentally responsible activities to cover this increased risk than smaller firms. 
It follows that:

H2a: There is a negative relation between the market value of equity and firm's size for the group of firms with a lower level of CSP but not for the group of firms with a higher level of CSP.

H2b1: The market undervalues larger firms with a lower level of CSP, when compared with firms with a higher level of CSP.

H2b2: The market does not undervalue larger firms with a lower level of CSP, when compared with firms with a higher level of CSP.

Waddock and Graves (1997) studied the link between firms' social and financial performance, hypothesizing that social performance is both a predictor and consequence of financial performance. They concluded that corporate social performance depends on financial performance and that the sign of the relationship is positive and interpret their findings as meaning that firms with slack resources potentially available from strong financial performance may have greater freedom to invest in socially and environmentally responsible activities, and that those investments may result in improved social performance.

Artiach et al. (2010) demonstrate that profitable firms are more likely to have a higher level of CSP. The managers of non-profitable firms are asked to reduce costs and maximize economic returns to financial stakeholders, instead of meet social stakeholder's demands through expenditure on sustainable activities. In periods of low economic performance, the companies' economic objectives will be given more attention than social concerns (Ullman, 1985).

On the other hand, companies which present abnormally high levels of profits are just as exposed to pressures from stakeholders as those of abnormally large companies or those that operate in socially-sensitive industries (Branco and Rodrigues, 2008). Public visibility may be related to high profits, with the more successful companies coming under more intense stakeholder scrutiny (ibid.).

It follows that: 
H3a: There is a negative relation between the market value of equity and firm's profitability for the group of larger firms with a lower level of CSP

H3b1: The market undervalues profitable larger firms with a lower level of CSP, when compared with firms with a higher level of CSP.

H3b2: The market does not undervalue profitable larger firms with a lower level of CSP, when compared with firms with a higher level of CSP. 


\section{RESEARCH DESIGN}

\subsection{SAMPLE AND DATA}

The empirical analysis relies on the largest 600 firms from Canada and the United States of America in the Dow Jones Global Total Stock Market Index (DJGTSM) at the end of 2009. These firms are classified into two groups, depending on whether they belong or not to the Dow Jones Sustainability North America Index (DJSI North America), as of September $2009^{2}$. This classification gives rise to the most important independent variable for our study, a proxy for the level of CSP.

Firms included in DJSI North America consist of the top 20\% of the 600 largest firms from Canada and the United States in the DJGTSM that lead the field in terms of sustainability (DJSI guidebook, 2010)³. Firm's sustainability is evaluated by the Sustainable Asset Management (SAM) Group. The SAM's methodology is based on the application of criteria to assess the opportunities and risks deriving from economic, environmental and social dimensions for each of the eligible firms (DJSI guidebook, 2010). The integrity of the DJSI as a proxy for CSP is highlighted in the report by Beleo et al. (2004), which recommends the SAM Group research as the best practice in corporate social responsibility research (Artiach et al., 2010. An increasing number of studies on the relation between CSP and firm performance use DJSI as a proxy for CSP (Lo and Sheu, 2007; López et al., 2007; Consolandi et al., 2009; Cheung, 2010).

The accounting data used in the empirical analysis is that reported in the annual consolidated financial statements with year-end between September 2009 and August 2010. The period for market data is selected based on the one of accounting data. The accounting and the market data was collected from the Thomson Worldscope Database. After excluding firms that lacked sufficient accounting or market value data, 507 valid firm observations remained. To ensure that the regression results are not unduly sensitive to outliers, we exclude observations with studentized residuals absolute value greater than 2 . This approach is consistent with some other value relevance studies (e.g. Hung and Subramanyam, 2007) ${ }^{4}$. Thus, the final sample is composed of 118 firms that belong to the DJSI North America (DJSI) and 360 firms that make no part of this index (Non_DJSI).

\footnotetext{
2 The DJSI North America is reviewed annually and quarterly. The annual review methodology selects the leading sustainability firms from the investable stocks universe and the resulting changes to the index are announced on the annual review date in September. The quarterly reviews reflect changes in the investable stocks universe as well as changes with regard to the number of shares and free float factors (DJSI guidebook, 2010). The index annual reviews are available at http://www.sustainability-index.com.

${ }^{3}$ The DJSI Guidebook is available at http://www.sustainability-index.com.

${ }^{4}$ See Curto et al. (2010) where the impact of influential observations on regression results is discussed.
} 
Table 1 presents the sample distribution across industries. When all the firms are considered together, the industrial sector is the most dominant with $36 \%$. The smallest representations, with $8 \%$ and $10 \%$, are the mining, the commercial and the services groups. As expected, both DJSI and Non_DJSI firms are found in each industry and the later predominates in all cases. The percentage of DJSI firms in each industry is between $20 \%$ and $30 \%$, except for the commercial and for the services groups, where the percentage is somewhat higher in the first case and lower in the second one. Considering only the Non_DJSI firms, a different distribution of firms across industry can be found when comparing the group of larger with the group of smaller firms. The proportion of the industrial sector (utilities and financial sectors) is higher (lower) in the group of smaller firms, when compared with the group of larger firms. The financial group is also characterized by a significant proportion of large but not profitable firms. However, the sensitivity analysis presented in Section 5 shows that our results are robust and they are not affected by these differences in the distribution of industrial, utilities and financial firms across different groups of firms based on their size and/or profitability.

\section{TABLE 1}

\subsection{RESEARCH METHOD}

To test the hypotheses formulated in Section 3, we estimate several regressions based on the same model, which relies on the accounting based valuation model developed in Ohlson (1995), who shows how the firm value relates to accounting data and other information. This approach is currently used in several empirical studies on the value relevance of non-financial information (e.g. Rajgopal et al., 2003; Hassel et al., 2005; Matolcsy and Wyatt, 2008; Johnston et al., 2008; Sinkin et al., 2008; Schadewitz and Niskala, 2010). Our primary model shows that the market value of equity is a function of two summary measures of information reflected in financial statements, namely the book value of equity and earnings, given by equation (1).

$$
M V_{i t}=\alpha_{0}+\alpha_{1} B V_{i t}+\alpha_{2} N I_{i t}+\varepsilon_{i t}
$$


where $M V$ is the market value of equity ${ }^{5}, B V$ represents the book value of equity and $N I$ is the net operating income. All the variables are on a per share basis. However, the sensitivity analysis presented in Section 5 shows that our results are not materially changed when we deflate by lagged market value of equity, or even by sales, instead of the number of common shares outstanding.

\subsubsection{The association of market value of equity with corporate sustainability performance}

In order to access whether the market undervalues firms with a lower level of CSP, when compared to firms with a higher level of CSP, we use a new regression equation, Equation (2), that comprises the variable Non_DJSI, which assumes the value 1 if the firm is not included in the DJSI North America and 0 otherwise. If the market undervalue firms with a lower level of corporate CSP, we would expect the coefficient on Non_DJSI, $\alpha_{3}$, to be negative and statistically significant.

$$
M V_{i t}=\alpha_{0}+\alpha_{1} B V_{i t}+\alpha_{2} N I_{i t}+\alpha_{3} N_{0}{ }_{-} D J S I_{i t}+\varepsilon_{i t}
$$

\subsubsection{The association of market value of equity with firm's size for different groups of firms based on the level of corporate sustainability performance}

In order to access whether there is a negative relation between the market value of equity and firm's size for the group of firms with a lower level of CSP but not for the group of firms with a higher level of CSP, we use a new regression equation, Equation (3), that comprises two interaction terms, Non_DJSI x SIZE and DJSI x SIZE. The SIZE is the natural logarithm of total assets; Non_DJSI is a binary variable that assumes the value 1 if the firm is not included in the DJSI North America and 0 otherwise; DJSI is a binary variable that assumes 1 if the firm is included in the DJSI North America and 0 otherwise.

If there is a negative relation between the market value of equity and firm's size in the group of firms with a lower level of CSP, we would expect the coefficient on Non_DJSI x SIZE, $\alpha_{3}$, to be negative and statistically significant. In respect of the group of firms with a higher level of CSP, two scenarios are acceptable: to find no relation or to find a positive relation between the market value of equity and firm's size. In the first case, we

\footnotetext{
${ }^{5}$ We use the market value of equity as of fiscal year-end. However, untabulated findings reveal that our inferences are not sensitive to using prices as of fiscal year-end or as of three months after fiscal year-end.
} 
would expect the coefficient on DJSI x SIZE, $\alpha_{4}$, to be statistically insignificant. In the second scenario, the coefficient is expected to be positive and statistically significant.

$$
M V_{i t}=\alpha_{0}+\alpha_{1} B V_{i t}+\alpha_{2} N I_{i t}+\alpha_{3} N_{0} n_{-} D J S I x \operatorname{SIZE}_{i t}+\alpha_{4} \text { DJSI } x \operatorname{SIZE}_{i t}+\varepsilon_{i t}
$$

In spite of the empirical study referred above, we go further to analyze whether the market distinguishes groups of firms with a lower level of CSP based on size. In order to access whether, for firms with a lower level of CSP, the market undervalues larger firms but, in contrast, it does not undervalue smaller firms, in both cases when compared with firms with a higher level of CSP, we use a new regression equation, Equation (4), that comprises two variables that split the Non_DJSI in two groups based on the firm's size (Non_DJSI_Big and Non_DJSI_Small). The variable Non_DJSI_Big assumes the value 1 if the firm has a lower level of CSP and its SIZE is above the median and 0 otherwise. The variable Non_DJSI_Small assumes the value 1 if the firm has a lower level of CSP and its SIZE is below the median and 0 otherwise. If the market undervalue only those firms with incentives to present a higher level of CSP but that do not engage on such strategy, ie, the larger firms not included in the DJSI North America, we would expect the coefficient on Non_DJSI_Big, $\alpha_{3}$, to be negative and statistically significant and the coefficient on Non_DJSI_Small, $\alpha_{4}$, to be statistically insignificant.

$$
M V_{i t}=\alpha_{0}+\alpha_{1} B V_{i t}+\alpha_{2} N I_{i t}+\alpha_{3} \text { Non_DJSI_Big } i t+\alpha_{4} \text { Non_DJSI_Small } i t+\varepsilon_{i t}
$$

\subsubsection{The association of market value of equity with firm's profitability for different groups of firms} based on the size and on the level of corporate sustainability performance

In order to access whether there is a negative relation between the market value of equity and firm's profitability for the group of larger firms with a lower level of CSP, but not for the group of smaller firms with a lower level of CSP as well as for the group of firms with a higher level of CSP, we consider a new regression equation, Equation (5), that comprises three interaction terms, Non_DJSI_Big x ROE, Non_DJSI_Small x ROE and DJSI x ROE.

The ROE is the firm's return on equity. If there is a negative relation between the market value of equity and firm's profitability in the group of larger firms with a lower level of CSP, we would expect the coefficient on 
Non_DJSI_Big x SIZE, $\alpha_{3}$, to be negative and statistically significant. In respect of the other groups of firms, two scenarios are also acceptable: to find no relation or to find a positive relation between the market value of equity and firm's profitability. In the first case, we would expect the coefficients on Non_DJSI_Small x ROE, $\alpha_{4}$, and on DJSI x ROE, $\alpha_{5}$, to be statistically insignificant. In the second scenario, the coefficients are expected to be positive and statistically significant.

$$
M V_{i t}=\alpha_{0}+\alpha_{1} B V_{i t}+\alpha_{2} N I_{i t}+\alpha_{3} N o n_{-} D J S I \_B i g x R O E_{i t}+\alpha_{4} N o n_{-} D J S I \_S m a l l x R O E_{i t}+\alpha_{5} D J S I x R O E_{i t}++\varepsilon_{i t}
$$

In spite of the analysis referred above, we again go further by analyzing whether the market distinguishes groups of larger firms with a lower level of CSP based on profitability. In order to access whether, for larger firms with a lower level of CSP, the market undervalues profitable firms but, in contrast, it does not undervalue non profitable firms, in both cases when compared with firms with a higher level of CSP, we use a new estimating equation, Equation (6), that comprises the variable Non_DJSI_Small and two variables that split the Non_DJSI_Big into two groups based on the firm's profitability (Non_DJSI_Big_Profit and Non_DJSI_Small_Loss). The variable Non_DJSI_Big_Profit assumes 1 if the firm has a lower level of CSP, its SIZE is above the median and its ROE is positive and 0 otherwise. The variable Non_DJSI_Big_Loss assumes 1 if the firm has a lower level of CSP, its SIZE is above the median and its ROE is negative and 0 otherwise. If the market undervalue only those firms with incentives to present a higher level of CSP but that do not engage on such strategy, ie, in this case the larger and profitable firms not included in the DJSI North America, we would expect the coefficient on Non_DJSI_Big_Profit, $\alpha_{3}$, to be negative and statistically significant and the coefficients on Non_DJSI_Big_Loss, $\alpha_{4}$, and on Non_DJSI_Small, $\alpha_{5}$, to be statistically insignificant.

$$
M V_{i t}=\alpha_{0}+\alpha_{1} B V_{i t}+\alpha_{2} N I_{i t}+\alpha_{3} \text { Non_DJSI_Big_Profit }{ }_{i t}+\alpha_{4} \text { Non_DJSI_Big_Loss }{ }_{i t}+\alpha_{5} \text { Non_DJSI_Small }{ }_{i t}+\varepsilon_{i t}
$$

Finally, and following previous literature on the value relevance of accounting numbers (e.g. Barth et. al, 2008), control variables are used in this study to control for profitability, leverage, size, international listing and industry. Thus, equations (2), (3), (4), (5) and (6) are estimated including the following variables: ROE, LEV, SIZE, LIST and Industry. ROE is the return on equity, LEV is end-of-year total debt divided by end-of-year market capitalization, SIZE is the natural logarithm of total assets as of the end of the year and List is a dummy 
variable that assumes the value 1 if the firm is listed in a foreign stock exchange and 0 otherwise. There are six dummies for industry: the Mining dummy which assumes one in the case of SIC 1 and 0 otherwise, the Industrial dummy which assumes 1 in cases of SIC 2 or 3 and 0 otherwise, the Utilities dummy which assumes 1 in the case of SIC 4 and 0 otherwise, the Commercial dummy which assumes 1 in cases of SIC 5 and 0 otherwise, the Financial dummy which assumes 1 in cases of SIC 6 and 0 otherwise and, finally, the Services dummy which assumes 1 in cases of SIC 7 or 8 and 0 otherwise.

\section{RESULTS}

\subsection{DESCRIPTIVE STATISTICS AND CORRELATIONS}

Table 2 presents the descriptive statistics for the entire sample as well as for the sub-samples of 118 DJSI firms and 360 Non_DJSI firms. When comparing the groups of DJSI and Non_DJSI firms, we find that for all the variables, except LEV, the mean and the median values are higher for the DJSI firms. However, untabulated results for equality of means parametric t-test show that the mean values are significantly different only for the variables MV, NI, ROE and SIZE. These findings are consistent with those of Artiach et al. (2010) in their study on the determinants of CSP. They found that leading CSP firms are significantly larger and have a higher return on equity than non-leading CSP firms.

\section{TABLE 2}

Table 3 presents correlations for the continuous variables included in the regressions. Consistent with established results in the accounting literature, the market value of equity is positively and significantly associated with BV and with NI. Not surprisingly, the market value is also significantly associated with ROE and LEV, with positive and negative relation, respectively.

TABLE 3

\subsection{REGRESSION RESULTS}




\subsubsection{The association of market value of equity with corporate sustainability performance}

Table 4 presents regression summary statistics resulting from the OLS estimation of Equation (2), including the estimated coefficients for the control variables. The regression in column $\mathrm{C} 1$ includes all the covariates. Columns C2-C4 drops individually from C1 three sets of variables, the Non_DJSI, the accounting variables and the control variables, respectively, in order to check if there are interaction effects within the three sets of independent variables. The coefficient estimate for the variable Non_DJSI is negative and statistically significant (coefficient $=-5.043 ;$ p-value $<0.01)$, which means that firms not included in the DJSI North America are associated with a lower market price, after considering the competing variables included in the regressions.

\section{TABLE 4}

The estimates for the accounting information are statistically significant and they have the expected sign. For example, in the main regression, the BV and NI coefficients are 0.694 and 3.220, respectively, and the associated $p$-value is $<0.01$ in both cases. The majority of the control variables are also statistically significant and their sign is in accordance with the literature. For example, profitable firms and firms listed in a foreign stock exchange are associated with a higher market price. By other hand, high leverage firms are associated with a lower market price. Contrary to the literature, the estimate for the variable SIZE is statistically significant but with a negative sign. Further analysis show that this variable is statistically significant but only when the variable Non_DJSI is also included in the regression (in C2, the SIZE is not statistically significant), which means that the relation between SIZE and MV is only observable for one of the groups of firms based on the sustainability criteria. The next section provides more detailed information on this issue.

\subsubsection{The association of market value of equity with firm's size for different groups of firms based on the level of corporate sustainability performance}

Table 5 presents regression summary statistics resulting from the OLS estimation of Equations (3) and (4), respectively, in columns $\mathrm{C} 1$ and $\mathrm{C} 2$.

\section{TABLE 5}


According to the results presented in column $\mathrm{C} 1$ of Table 5, the coefficient estimate for the interaction term of SIZE with Non_DJSI is statistically significant and negative (coefficient $=-2.596$; $p$-value $<0.01$ ) while the coefficient estimate for the interaction term of SIZE with DJSI is statistically insignificant. As expected, in the group of firms not included in the DJSI North America, the higher the firm's size, the lower the market value of equity. The results presented in column $\mathrm{C} 2$ of Table 5 provide additional information on this issue. The coefficient estimate for the variable Non_DJSI_Big is negative and statistically significant (coefficient $=-5.841$; $p$-value $<0.01$ ), while the coefficient estimate for Non_DJSI_Small is statistically insignificant. These results show that the market does not undervalue all the firms with a lower level of CSP. By contrast, the market undervalue only those firms with incentives to present a high level of CSP (large firms) but that do not engage on such strategy, ie, the group of the larger firms not included in the DJSI North America.

5.2.3. The association of market value of equity with firm's profitability for different groups of firms based on the size and on the level of corporate sustainability performance

Table 6 presents regression summary statistics resulting from the OLS estimation of Equations (5) and (6), respectively, in columns $\mathrm{C} 1$ and $\mathrm{C} 2$.

\section{TABLE 6}

According to the results presented in column $\mathrm{C} 1$ of Table 6, the coefficient estimate for the interaction term of ROE with Non_DJSI_Big is statistically significant and negative (coefficient $=-14.839$; $p$-value $<0.01$ ). In contrast, the coefficient estimates for the interaction terms of ROE with Non_DJSI_Big and with DJSI are both statistically significant and positive (Non_DJSI_Small $\mathrm{x}$ ROE coefficient $=5.437 ; p$-value $<0.01$; DJSI $\mathrm{x}$ ROE coefficient $=7.633 ;$-value $<0.01)$. As expected, in the group of larger firms not included in the DJSI North America, the higher the firm's profitability, the lower the market value of equity. The results presented in column $\mathrm{C} 2$ of Table 6 provide additional information on this issue. The coefficient estimate for the variable Non_DJSI_Big_Profit is negative and statistically significant (coefficient $=-6.602 ; p$-value $<0.01$ ), while the coefficient estimates for Non_DJSI_Big_Loss and for Non_DJSI_Small are both statistically insignificant. These 
results show that the market does not undervalue all the larger firms with a lower level of CSP, but only those that are profitable.

Overall, our findings seem to suggest that size and profitability is an issue that matters in terms of CSP. The information on the relation between size and profitability and the level of CSP is value relevant for the market.

\section{SUMMARY AND CONCLUSIONS}

In this paper, companies are considered to engage in CS because they expect that conforming to stakeholder norms and expectations about how their operations should be conducted allows them to have good relations with them. This is likely to lead to increased performance, namely by assisting in developing valuable intangible assets (resources and capabilities) which can be sources of competitive advantage because such assets can differentiate a company from its competitors.

This study investigates the way as the market views CSP, as proxied by membership of the Dow Jones Sustainability Index. Using a multi-theoretical framework which combines stakeholder and resource-based perspectives, a set of hypotheses is developed that relate the market value of equity with CSP, considering the interaction of size and profitability with CSP.

Our preliminary results indicate that CSP has significant explanatory power for stock prices over the traditional summary accounting measures such as earnings and book value of equity. However, further analyses suggest that we should not focus on the corporate sustainability itself. Our findings show that what investors really do is to undervalue large profitable firms with low level of corporate sustainability performance, which face greater public scrutiny and pressures from stakeholders.

The findings in this study are important to the ongoing debate about the financial consequences of corporate investment in sustainability activities. The current study focuses on the impact of incentives to invest in CS on the market valuation of CSP strategy. 


\section{REFERENCES}

Artiach, T., Lee, D., Nelson, D. and Walker, J., (2010), "The Determinants of Corporate Sustainability Performance", Accounting and Finance, Vol. 50, pp. 31-51.

Bansal, P. (2005), "Evolving sustainability: A longitudinal study of corporate sustainable development", Strategic Management Journal, Vol. 26, No. 3, pp. 197-218.

Bansal, P. and Roth, K. (2000), "Why companies go green: a model of ecological responsiveness", Academy of Management Journal, Vol. 13, No. 4, pp. 717-736.

Barney, J. B. (1999), “How a firm's capabilities affect boundary decisions”, Sloan Management Review, Vol. 40, No. 3, pp. 137-145.

Barth, M., Landsman. W. and Lang. M., (2008), “International Accounting Standards and Accounting Quality”, Journal of Accounting Research, Vol. 46, pp. 467-498.

Baumgartner, R. J. and Ebner, D. (2010), “Corporate Sustainability Strategies: Sustainability Profiles and Maturity Levels", Sustainable Development, Vol. 18, No. 2, pp. 76-89.

Bowman, C. and Ambrosini, V. (2003), "How the resource-based and the dynamic capability views of the firm inform corporate-level strategy”, British Journal of Management, Vol. 14, No. 4, pp. 289-303.

Brammer, S. and Pavelin, S. (2004), "Voluntary social disclosures by large UK companies", Business Ethics: A European Review, Vol. 13, No. 2/3, pp. 86-99.

Brammer, S., Millington, A. and Rayton, B. (2007), "The contribution of corporate social responsibility to organizational commitment", The International Journal of Human Resource Management, Vol. 18, No. 10, pp. 1701-1719.

Branco, M. C. and Rodrigues, L. L. (2008), "Social responsibility disclosure: A study of proxies for the public visibility of Portuguese banks", The British Accounting Review, Vol. 40, No. 2, pp. 161-181.

Branco, M. C. and Rodrigues, L. L. (2006), "Corporate social responsibility and resource based perspectives", Journal of Business Ethics, Vol. 69, No. 2, pp. 111-132.

Carmeli, A., Gilat, G. and Waldman, D. A. (2007), "The role of perceived organizational performance in organizational identification, adjustment and job performance”, Journal of Management Studies, Vol. 44, No. 6, pp. 837-1056.

Cheung, A., (2010), "Do Stock Investors Value Corporate Sustainability? Evidence from an event study", Journal of Business Ethics, forthcoming. 
Cochran, P. L. and Wood, R. A. (1984), “Corporate social responsibility and financial performance”, Academy of Management Journal, Vol. 27, No. 1, pp. 42-56.

Consolandi, C., Jaiswal-Dale, A. Poggiani, E. and Vercelli, A. (2009), "Global Standards and Ethical Stock Indexes: The Case of the Dow Jones Sustainability Stoxx Index”, Journal of Business Ethics, Vol. 87, pp. 185197.

Curran, M. M. and Moran, D. (2007), “Impact of the FTSE4Good Index on firm price: An event study”, Journal of Environmental Management, Vol. 82, pp. 529-537.

Curto, J., Morais, A., Lourenço, I. and Pinto, J. (2011), “The heteroskedasticity-consistent Covariance Estimator in Accounting", Review of Quantitative Finance and Accounting, forthcoming.

Dyllick, T. and Hockerts, K. (2002), "Beyond the business case for corporate sustainability”, Business Strategy and the Environment, Vol. 11, pp. 130-141.

Falck, O. and Heblich, S. (2007), "Doing well by doing good”, Business Horizons, Vol. 50, pp. 247-254.

Fombrun, C. and Shanley, M. (1990), "What's in a name? Reputation building and corporate strategy", Academy of Management Journal, Vol. 33, pp. 233-258.

Fombrun, C., Gardberg, N. and Barnett, M. (2000), “Opportunity Platforms and Safety Nets: Corporate Citizenship and Reputational Risk”, Business and Society Review, Vol. 105, No. 1, pp. 85-106.

Gallego-Álvarez, I., Prado-Lorenzo, J.-M., Rodríguez-Domínguez, L. and García-Sánchez, I.-M. (2010), “Are social and environmental practices a marketing tool? Empirical evidence for the biggest European companies", Management Decision, Vol. 48, No. 10, pp. 1440-1455.

Garcia-Castro, R., Ariño, M. A. and Canela, M. A. (2010), "Does Social Performance Really Lead to Financial Performance? Accounting for Endogeneity”, Journal of Business Ethics, Vol. 92, pp.107-126.

Godfrey, P. C., Merrill, C. G. and Hansen, J. M. (2009), "The relationship between corporate social responsibility and shareholder value: An empirical test of the risk management hypothesis", Strategic Management Journal, Vol. 30, No. 4, pp. 425-445.

Hassel, L., Nilsson, H. and Nyquist, S. (2005), "The Value Relevance of Environmental Performance", European Accounting Review, Vol. 14, No. 1, pp. 41-61.

Hayn, C., (1995), “The Information Content of Losses”, Journal of Accounting and Economics, Vol. 26, pp. 125-153.

Heslin, P. A. and Ochoa, J. D. (2008), "Understanding and developing strategic corporate social responsibility", Organizational Dynamics, Vol. 37, No. 2, pp. 125-144. 
Hillman, A. J. and Keim, G. D. (2001), "Shareholder value, stakeholder management, and social issues: What's the bottom line?", Strategic Management Journal, Vol. 22, No. 2, pp. 125-139.

Hughes, K., (2000), "The Value Relevance of Nonfinancial Measures of Air Pollution in the Electric Utility Industry", The Accounting Review, Vol. 75, No. 2, pp. 209-228.

Holme, R. and Watts, P. (2000), Corporate Social Responsibility: making good business sense, World Business Council for Sustainable Development.

Hung, M. and Subramanyam, K. (2007), "Financial Statement Effects of Adopting International Accounting Standards: the case of Germany", Review of Accounting Studies, Vol. 12, pp. 623-657.

Hussainey, K. and Salama, A. (2010), "The importance of corporate environmental reputation to investors", Journal of Applied Accounting Research, Vol. 11, No. 3, pp. 229-241.

Johnston, D., Sefcik, S. And Soderstrom, N. (2008), “The Value Relevance of Greenhouse Gas Emissions Allowances: an Exploratory Study in the Related United States SO2 Market”, European Accounting Review, Vol. 17, No. 4, pp. 747-764.

Konar, S. And Cohen, M. (2001), "Does the Market Value Environmental performance?", The Review of Economics and Statistics, Vol. 82, No. 2, pp. 281-289.

Kraaijenbrink, J., Spender J.-C. and Groen, A. J. (2010), “The Resource-Based View: A Review and Assessment of Its Critiques", Journal of Management, Vol. 36, pp. 349-372.

Lo, S. and Sheu, H. (2007), “Is Corporate Sustainability a Value-Increasing Strategy for Business?”, Corporate Governance, Vol. 15, No. 2, pp. 345-358.

Margolis, J. D. and Walsh, J. P. (2003), "Misery loves firms: rethinking social initiatives by business", Administrative Science Quarterly, Vol. 48 No. 2, pp. 268-305.

Matolcsy, Z. and Wyatt, A. (2008), “The Association between Technological Conditions and the Market Value of Equity", The Accounting Review, Vol. 83, No. 2, pp. 479-518.

McWilliams, A. and Siegel, D. (2001), "Corporate social responsibility: A theory of the firm perspective", Academy of Management Review, Vol. 26, No. 1, pp. 117-127.

McWilliams, A., Siegel, D. and Wright, P. M. (2006), “Corporate social responsibility: Strategic implications”, Journal of Management Studies, Vol. 43, No. 1, pp. 1-18.

Menz, M. (2010), “Corporate Social Responsability: it is rewarded by the corporate bond market?”, Journal of Business Ethics, Vol. 96, pp. 117-134. 
Moskowitz, M. R. (1972), “Choosing socially responsible stocks”, Business and Society Review, Vol. 1, pp. 715.

Niskala, M. and Schadewitz, H. J. (2010), "Communication via responsibility reporting and its effect on firm value in Finland", Corporate Social Responsibility and Environmental Management, Vol. 17, No. 2, pp. 96106.

Orlitzky, M. (2008), “Corporate Social Performance and Financial Performance: A Research Synthesis", in Crane, A., McWilliams, A., Matten, D., Moon, J., Siegel, D. S. (eds.), The Oxford Handbook of Corporate Social Responsibility, Oxford University Press.

Orlitzky, M., Schmidt, F. L. and Rynes, S. L. (2003), "Corporate social and financial performance: A metaanalysis”, Organization Studies, Vol. 24, No. 3, pp. 403-441.

Pertusa-Ortega, E. M., Molina-Azorín, J. F. and Claver-Cortés, E. (2010), "Competitive strategy, structure and firm performance: A comparison of the resource-based view and the contingency approach", Management Decision, Vol. 48, No. 8, pp. 1282-1303.

Post, J. E., Preston, L. E. and Sachs, S. (2002) "Managing the Extended Enterprise: The New Stakeholder View”, California Management Review, Vol. 45 No. 1, pp. 6-28.

Porter, M. E. and Kramer, M. R. (2002), “The competitive advantage of corporate philanthropy”, Harvard Business Review, Vol. 80, No. 12, pp. 56-68.

Porter, M. E. and Kramer, M. R. (2006), "Strategy and society: The link between competitive advantage and corporate social responsibility”, Harvard Business Review, Vol. 84, No. 12, pp. 78-92.

Rajopal, S.; Venkatachalam, M. and Kotha, S. (2002), “The Value Relevance of Network Advantages: the Case of E-Commerce Firms”, Journal of Accounting Research, Vol. 41, No. 1, pp. 135-162.

Roman, R. M., Hayibor, S. and Agle, B. R. (1999), “The relationship between social and financial performance”, Business and Society, Vol. 38, No. 1, pp. 109-125.

Salzmann, O., Ionescu-Somers, A. and Steger, U. (2005), "The business case for corporate sustainability: literature review and research options”, European Management Journal, Vol. 23 No. 1, pp. 27-36.

Sasse, C. M. and Trahan, R. T. (2007), "Rethinking the new corporate philanthropy”, Business Horizons, Vol. 50, pp. 29-38.

Siegel, D. S. (2009), “Green Management Matters Only If It Yields More Green: An Economic/Strategic Perspective," Academy of Management Perspectives, Vol. 23, No. 3, pp. 5-16. 
Sinkin, C., Wright, C. J. and Burnett, R. D. (2008, "Eco-efficiency and firm value", Journal of Accounting and Public Policy, Vol. 27, pp. 167-176.

Surroca, J., Tribó, J. A. and Waddock, S. (2010), "Corporate Responsibility and Financial Performance: The Role of Intangible Resources", Strategic Management Journal, Vol. 31, No. 5, pp. 463-490.

Valor, C. (2005), "Corporate social responsibility and corporate citizenship: Towards corporate accountability", Business and Society Review, Vol. 110, No. 2, pp. 191-212.

van Marrewijk, M. (2003), "Conceptions and definitions of CSR and corporate sustainability: Between agency and communion", Journal of Business Ethics, Vol. 44, No. 2/3, pp. 95-105.

van Beurden, P. and Gössling, T. (2008), "The worth of values - a literature review on the relation between corporate social and financial performance", Journal of Business Ethics, Vol. 82, pp.407-24.

van Dijken, F. (2007), "Corporate social responsibility: market regulation and the evidence", Managerial Law, Vol. 49, No. 4, pp. 141-184.

Vance, S.C. (1975), “Are socially responsible corporations good investment risks?”, Management Review, Vol. 64, pp. 18-24.

Vitaliano, D. F. (2010), “Corporate social responsibility and labor turnover”, Corporate Governance, Vol. 10, No. 5, pp. 563-573

Wagner, M. (2010), “The role of corporate sustainability performance for economic performance: A firm-level analysis of moderation effects", Ecological Economics, Vol. 69, pp. 1553-1560.

Wahba H. (2008), "Does the market value corporate environmental responsibility? An empirical examination", Corporate Social Responsibility and Environmental Management, Vol. 15, No. 2, pp. 89-99.

Wood, D. J. and Jones, R. E. (1995) "Stakeholder mismatching: a theoretical problem in empirical research on corporate social performance", The International Journal of Organizational Analysis, Vol. 3 No. 3, pp. 229267.

Wu, M.-L. (2006), “Corporate Social Performance, Corporate Financial Performance, and Firm Size: A MetaAnalysis", The Journal of American Academy of Business, Vol. 8, No. 1, pp. 163-171. 


\section{TABLE 1}

Sample composition by industry

\begin{tabular}{llcccccc} 
& & \multicolumn{2}{c}{ DJSI firms } & Non_DJSI firms & \multicolumn{2}{c}{ All firms } \\
\hline Industry & SIC Code & $\mathbf{n}$ & \% & n & \% & n & $\%$ \\
\hline Mining & SIC 1 & 10 & $8 \%$ & 27 & $8 \%$ & 37 & $8 \%$ \\
Industrial & SIC 2 and 3 & 44 & $37 \%$ & 128 & $36 \%$ & 172 & $36 \%$ \\
Utilities & SIC 4 & 19 & $16 \%$ & 52 & $14 \%$ & 71 & $15 \%$ \\
Commercial & SIC 5 & 16 & $14 \%$ & 33 & $9 \%$ & 49 & $10 \%$ \\
Financial & SIC 6 & 22 & $19 \%$ & 78 & $22 \%$ & 100 & $21 \%$ \\
Services & SIC 7 and 8 & 7 & $6 \%$ & 42 & $12 \%$ & 49 & $10 \%$ \\
\cline { 2 - 7 } & & 118 & $100 \%$ & 360 & $100 \%$ & 478 & $100 \%$ \\
\hline
\end{tabular}

\section{Non_DJSI_Big firms Non_DJSI_Small firms $\quad$ Non_DJSI firms}

\begin{tabular}{llllllll}
\hline Industry & SIC Code & $\mathbf{n}$ & $\mathbf{\%}$ & $\mathbf{n}$ & $\mathbf{\%}$ & $\mathbf{N}$ & $\mathbf{\%}$ \\
\hline Mining & SIC 1 & 10 & $6 \%$ & 17 & $9 \%$ & 27 & $8 \%$ \\
Industrial & SIC 2 and 3 & 46 & $26 \%$ & 82 & $45 \%$ & 128 & $36 \%$ \\
Utilities & SIC 4 & 38 & $21 \%$ & 14 & $8 \%$ & 52 & $14 \%$ \\
Commercial & SIC 5 & 12 & $7 \%$ & 21 & $12 \%$ & 33 & $9 \%$ \\
Financial & SIC 6 & 60 & $34 \%$ & 18 & $10 \%$ & 78 & $22 \%$ \\
Services & SIC 7 and 8 & 13 & $7 \%$ & 29 & $16 \%$ & 42 & $12 \%$ \\
\cline { 2 - 7 } & & 179 & $100 \%$ & 181 & $100 \%$ & 360 & $100 \%$ \\
\hline
\end{tabular}

\begin{tabular}{llcccccc} 
& & \multicolumn{2}{c}{$\begin{array}{c}\text { Non_DJSI_Big } \\
\text { Profit firms }\end{array}$} & $\begin{array}{c}\text { Non_DJSI_Big_Loss } \\
\text { firms }\end{array}$ & Non_DJSI_Big firms \\
\hline Industry & SIC Code & n & \% & n & \% & n & \% \\
\hline Mining & SIC 1 & 6 & $4 \%$ & 4 & $11 \%$ & 10 & $6 \%$ \\
Industrial & SIC 2 and 3 & 39 & $28 \%$ & 7 & $20 \%$ & 46 & $26 \%$ \\
Utilities & SIC 4 & 36 & $25 \%$ & 2 & $6 \%$ & 38 & $21 \%$ \\
Commercial & SIC 5 & 12 & $8 \%$ & 0 & $0 \%$ & 12 & $7 \%$ \\
Financial & SIC 6 & 40 & $28 \%$ & 20 & $56 \%$ & 60 & $34 \%$ \\
Services & SIC 7 and 8 & 10 & $7 \%$ & 3 & $8 \%$ & 13 & $7 \%$ \\
\cline { 2 - 7 } & & 143 & $100 \%$ & 36 & $100 \%$ & 179 & $100 \%$ \\
\hline
\end{tabular}

DJSI firms are those included in the DJSI North America; Non_DJSI firms are those not included in the DJSI North America; Non_DJSI_Big are those firms not included in the DJSI North America whose size is above the median; Non_DJSI_Small are those firms not included in the DJSI North America whose size is below the median; Non_DJSI_Big_Profit are the profitable firms not included in the DJSI North America whose size is above the median; Non_DJSI_Loss are the non profitable firms not included in the DJSI North America whose size is above the median. 
TABLE 2

Descriptive statistics

\begin{tabular}{|c|c|c|c|c|c|c|c|}
\hline & Mean & Median & SD & Min & Max & Skewness & Kurtosis \\
\hline \multicolumn{8}{|c|}{ All firms $(n=478)$} \\
\hline MV & 34.421 & 31.805 & 18.252 & 1.530 & 98.420 & 0.608 & 0.045 \\
\hline BV & 17.713 & 14.703 & 12.488 & 0.062 & 79.096 & 1.365 & 2.365 \\
\hline NI & 1.535 & 1.629 & 2.307 & -10.570 & 10.551 & -0.670 & 4.487 \\
\hline ROE & 0.126 & 0.110 & 0.314 & -1.425 & 3.201 & 3.729 & 35.424 \\
\hline LEV & 0.711 & 0.312 & 1.746 & 0.000 & 29.536 & 11.030 & 163.876 \\
\hline SIZE & 7.223 & 7.158 & 0.569 & 6.092 & 9.347 & 0.789 & 0.924 \\
\hline \multicolumn{8}{|c|}{ DJSI firms $(n=118)$} \\
\hline MV & 39.986 & 36.590 & 19.330 & 3.310 & 83.490 & 0.380 & -0.607 \\
\hline $\mathrm{BV}$ & 18.630 & 17.285 & 11.477 & 0.966 & 48.962 & 0.751 & 0.069 \\
\hline NI & 2.151 & 2.149 & 1.917 & -4.914 & 6.917 & -0.334 & 1.132 \\
\hline ROE & 0.186 & 0.131 & 0.371 & -0.587 & 3.201 & 5.451 & 39.978 \\
\hline LEV & 0.598 & 0.273 & 1.119 & 0.000 & 9.020 & 5.106 & 31.802 \\
\hline SIZE & 7.533 & 7.448 & 0.574 & 6.370 & 9.308 & 0.850 & 0.755 \\
\hline \multicolumn{8}{|c|}{ Non_DJSI firms $(n=360)$} \\
\hline MV & 32.597 & 30.350 & 17.530 & 1.530 & 98.420 & 0.674 & 0.387 \\
\hline BV & 17.412 & 13.732 & 12.803 & 0.062 & 79.096 & 1.526 & 2.920 \\
\hline NI & 1.333 & 1.501 & 2.390 & -10.570 & 10.551 & -0.660 & 4.831 \\
\hline ROE & 0.107 & 0.104 & 0.291 & -1.425 & 2.641 & 2.483 & 28.391 \\
\hline LEV & 0.748 & 0.320 & 1.908 & 0.000 & 29.536 & 10.889 & 151.280 \\
\hline SIZE & 7.121 & 7.054 & 0.530 & 6.092 & 9.347 & 0.796 & 1.036 \\
\hline
\end{tabular}

DJSI firms are those included in the DJSI North America; Non_DJSI firms are those not included in the DJSI North America.

$M V$ is the market price at the fiscal year-end; $B V$ is the book value of equity as of the end of the year; $N I$ is the net income of the year; $R O E$ is the return on equity; $L E V$ is end-of-year total debt divided by end-of-year market capitalization; SIZE is the natural logarithm of total assets as of the end of the year. 
TABLE 3

\section{Correlation matrix}

\begin{tabular}{lcccccc} 
& MV & BV & NI & ROE & LEV & SIZE \\
\hline MV & 1 & - & - & - & - & - \\
BV & $0.531 * * *$ & 1 & - & - & - & - \\
NI & $0.478 * * *$ & $0.312 * * *$ & 1 & - & - & - \\
ROE & $0.263 * * *$ & $-0.139 * * *$ & $0.434 * * *$ & 1 & - & - \\
LEV & $-0.232 * * *$ & 0.003 & $-0.167 * *$ & $-0.132 * * *$ & 1 & $0.304 * * *$ \\
SIZE & 0.053 & $0.362 * * *$ & 0.072 & -0.059 & 1 \\
\hline
\end{tabular}

$M V$ is the market price at the fiscal year-end; $B V$ is the book value of equity as of the end of the year; $N I$ is the net income of the year; $R O E$ is the return on equity; $L E V$ is end-of-year total debt divided by end-of-year market capitalization; SIZE is the natural logarithm of total assets as of the end of the year. 
TABLE 4

First hypothesis test:

the association of market value of equity with corporate sustainability performance

\begin{tabular}{|c|c|c|c|c|c|}
\hline & Exp. Sign & C1 & $\mathrm{C2}$ & C3 & C4 \\
\hline Intercept & & $36.581 * * *$ & $20.310^{* *}$ & -0.956 & $21.367 * * *$ \\
\hline \multicolumn{6}{|l|}{ Main variables: } \\
\hline $\mathrm{BV}$ & + & $0.694 * * *$ & $0.676^{* * *}$ & & $0.546^{* * *}$ \\
\hline NI & + & $3.220 * * *$ & $3.319 * * *$ & & $3.929 * * *$ \\
\hline Non_DJSI & - & $-5.043 * * *$ & & $-4.858 * *$ & $-3.510 * * *$ \\
\hline \multicolumn{6}{|c|}{ Control variables: } \\
\hline ROE & + & $5.165 * *$ & $5.531 * * *$ & $11.779 * * *$ & \\
\hline LEV & - & $-0.694 * *$ & $-0.805 * *$ & $-2.050 * * *$ & \\
\hline SIZE & + & $-2.372 *$ & -0.670 & $5.197 * * *$ & \\
\hline LIST & + & $4.144^{*}$ & $4.516^{* * *}$ & 4.285 & \\
\hline Mining & & $3.580^{*}$ & $3.973^{*}$ & 3.386 & \\
\hline Utilities & & $-5.611 * * *$ & $-5.703 * * *$ & -3.490 & \\
\hline Commercial & & $-7.132 * *$ & 3.274 & $-9.886^{* *}$ & \\
\hline Financial & & $-7.691 * * *$ & $-8.329 * * *$ & $-7.514 * * *$ & \\
\hline Services & & -0.982 & -0.932 & -3.825 & \\
\hline Adjusted $\mathrm{R}^{2}$ & & 0.596 & 0.586 & 0.156 & 0.520 \\
\hline F-Value & & $59.639 * * *$ & $64.432 * * *$ & $9.801 * * *$ & $173.578 * * *$ \\
\hline
\end{tabular}

Dependent variable: $M V$ (market price at the fiscal year-end).

Independent variables: $B V$ (book value of equity as of the end of the year); NI (net income of the year); Non_DJSI (an indicator that equals 1 if the firm is not included in the DJSI North America and 0 otherwise); $R O E$ (return on equity); $L E V$ (end-of-year total debt divided by endof-year market capitalization); SIZE (natural logarithm of total assets as of the end of the year); LIST (an indicator that equals 1 if the firm is listed in a foreign stock exchange and 0 otherwise); Industry variables: Mining (SIC 1); Utilities (SIC 4); Commercial (SIC 5); Financial (SIC 6) and Services (SIC 7 and SIC 8).

$* * *, * *$ and $*$ indicate significance at the $0.01,0.05$ and 0.10 levels respectively. 
TABLE 5

Second hypothesis test:

the association of market value of equity with firm's size for different groups of firms based on the level of CSP

\begin{tabular}{|c|c|c|c|}
\hline & Exp. Sign & C1 & $\mathrm{C} 2$ \\
\hline Intercept & & $33.013 * * *$ & $21.872 *$ \\
\hline \multicolumn{4}{|l|}{ Main variables: } \\
\hline $\mathrm{BV}$ & + & $0.695^{* * *}$ & $0.703 * * *$ \\
\hline NI & + & $3.212 * * *$ & $3.201 * * *$ \\
\hline Non_DJSI x SIZE & - & $-2.596 * *$ & \\
\hline DJSI x SIZE & & -1.904 & \\
\hline Non_DJSI_Big & - & & $-5.841 * * *$ \\
\hline Non_DJSI_Small & & & -2.485 \\
\hline \multicolumn{4}{|l|}{ Control variables: } \\
\hline ROE & + & $5.182 * *$ & $5.079 * *$ \\
\hline LEV & - & $-0.690 * *$ & $-0.708 * *$ \\
\hline SIZE & + & & -0.518 \\
\hline LIST & + & $4.218^{*}$ & $4.669 * *$ \\
\hline Mining & & $3.595^{*}$ & 3.449 \\
\hline Utilities & & $-5.572 * * *$ & $-5.229 * * *$ \\
\hline Commercial & & $-6.979 * *$ & $-6.242 *$ \\
\hline Financial & & $-7.678 * * *$ & $-7.896^{* * *}$ \\
\hline Services & & -0.975 & -0.867 \\
\hline Adjusted $R^{2}$ & & 0.597 & 0.599 \\
\hline F-Value & & $59.790 * * *$ & $55.708 * * *$ \\
\hline
\end{tabular}

Dependent variable: $M V$ (market price at the fiscal year-end).

Independent variables: $B V$ (book value of equity as of the end of the year); $N I$ (net income of the year); DJSI (an indicator that equals 1 if the firm is included in the DJSI North America and 0 otherwise); Non_DJSI (an indicator that equals 1 if the firm is not included in the DJSI North America and 0 otherwise); Non_DJSI_Big (an indicator that equals 1 if the firm is not included in the DJSI North America and his size is above the median); Non_DJSI_Small (an indicator that equals 1 if the firm is not included in the DJSI North America and his size is below the median); ROE (return on equity); LEV (end-of-year total debt divided by end-of-year market capitalization); SIZE (natural logarithm of total assets as of the end of the year); LIST (an indicator that equals 1 if the firm is listed in a foreign stock exchange and 0 otherwise); Industry variables: Mining (SIC 1); Utilities (SIC 4); Commercial (SIC 5); Financial (SIC 6) and Services (SIC 7 and SIC 8).

$* * *, * *$ and $*$ indicate significance at the $0.01,0.05$ and 0.10 levels respectively. 
TABLE 6

Third hypothesis test

the association of market value of equity with firm's profitability for different groups of firms based on the size and on the level of CSP

\begin{tabular}{|c|c|c|c|}
\hline & Exp. Sign & C1 & $\mathbf{C 2}$ \\
\hline Intercept & & $17.630 * *$ & $22.876^{*}$ \\
\hline \multicolumn{4}{|l|}{ Main variables: } \\
\hline BV & + & $0.667 * * *$ & $0.690^{* * *}$ \\
\hline NI & + & $3.723 * * *$ & $3.498^{* * *}$ \\
\hline Non_DJSI_Big x ROE & - & $-14.839^{* * *}$ & \\
\hline Non_DJSI_Small x ROE & + & $5.437 * *$ & \\
\hline DJSI $x$ ROE & + & $7.663 * * *$ & \\
\hline Non_DJSI_Big_Profit & - & & $-6.602 * * *$ \\
\hline Non_DJSI_Big_Loss & & & -1.429 \\
\hline Non_DJSI_Small & & & -2.419 \\
\hline \multicolumn{4}{|l|}{ Control variables: } \\
\hline ROE & + & & $4.974 * *$ \\
\hline LEV & - & $-0.859 * *$ & $-0.724 * *$ \\
\hline SIZE & + & -0.293 & -0.677 \\
\hline LIST & + & $4.528 * *$ & $4.447 * *$ \\
\hline Mining & & $3.864 *$ & 3.438 \\
\hline Utilities & & $-5.375 * * *$ & $-4.915^{* * *}$ \\
\hline Commercial & & -3.925 & $-6.136^{*}$ \\
\hline Financial & & $-8.589 * * *$ & $-8.033 * * *$ \\
\hline Services & & -0.877 & -0.834 \\
\hline Adjusted $\mathrm{R}^{2}$ & & 0.599 & 0.601 \\
\hline F-Value & & $55.848 * * *$ & $52.380 * * *$ \\
\hline
\end{tabular}

Dependent variable: $M V$ (market price at the fiscal year-end).

Independent variables: $B V$ (book value of equity as of the end of the year); $N I$ (net income of the year); Non_DJSI_Big (an indicator that equals 1 if the firm is not included in the DJSI North America and his size is above the median); Non_DJSI_Small (an indicator that equals 1 if the firm is not included in the DJSI North America and his size is below the median); DJSI (an indicator that equals 1 if the firm belongs to the DJSI North America and 0 otherwise); Non_DJSI_Big_Profit (an indicator that equals 1 if the firm is not included in the DJSI North America, his size is above the median and ROE is positive); Non_DJSI_Big_Loss (an indicator that equals 1 if the firm is not included in the DJSI North America, his size is above the median and ROE is negative); ROE (return on equity); $L E V$ (end-of-year total debt divided by endof-year market capitalization); SIZE (natural logarithm of total assets as of the end of the year); LIST (an indicator that equals 1 if the firm is listed in a foreign stock exchange and 0 otherwise); Industry variables: Mining (SIC 1); Utilities (SIC 4); Commercial (SIC 5); Financial (SIC 6) and Services (SIC 7 and SIC 8).

***, ** and * indicate significance at the $0.01,0.05$ and 0.10 levels respectively. 